\title{
Conversion disorder with sudden visual loss: A case report
}

\section{Ani görme kaybı ille giden konversiyon bozukluğu: Bir olgu sunumu}

\author{
Sedla Aybuke Sarı, Ayla Uzun Çiçek, Özge Düzgüin
}

Cumhuriyet University Medical Faculty Child and Adolescent Psychiatry Department Sivas, Turke

Corresponding author: Seda Aybuke Sar1, MD, Cumhuriyet University Medical Faculty Child and Adolescent Psychiatry Department Sivas, Turkey E-mail: aybuke_sari@hotmail.com

Received/Accepted: August 12, 2020 / September 22, 2020

Conflict of interest: There is not a conflict of interest.

\section{SUMMARY}

Conversion Disorder (CD) is a psychiatric disorder characterized by the presence of one or more neurological or vegetative symptoms that cannot be better explained by any organic pathology. CD can mimic many organic diseases. Therefore, general medical diseases, neurological and psychiatric disorders should be considered in the differential diagnosis. It is not always easy to distinguish conversion disorder from these diseases.

In this case report, we presented a female case whose mother had vision loss due to retinitis pigmentosa and who was also investigated for sudden vision loss and did not have any organic pathology and consequently diagnosed with conversion disorder.

Keywords: Conversion disorder, children, sudden visual loss
Seda Aybuke Sarı

Ayla Uzun Çiçek

Özge Düzgün
ORCID IDs of the authors:

S.A.S. 0000-0003-4793-0662

A.U.Ç. 0000-0003-2274-3457

Ö.D. 0000-0003-4250-0217

ÖZET

Konversiyon Bozukluğu (KB), herhangi bir organik patoloji ile daha iyi açıklanamayan bir veya daha fazla nörolojik veya vejetatif semptomun varlığı ile karakterize bir psikiyatrik bozukluktur. KB, birçok organik hastalığ1 taklit edebilir. Bu nedenle ayırıcı tanıda genel tıbbi hastalıklar, nörolojik ve psikiyatrik bozukluklar düşünülmelidir. Konversiyon bozukluğunu bu hastalıklardan ayırmak her zaman kolay değildir.

Bu olgu sunumunda annesinde retinitis pigmentosa nedeniyle görme kaybı olan, ani görme kaybı için araştırılan, organik patolojisi olmayan ve buna bağlı olarak konversiyon bozukluğu tanısı konulan bir kız olguyu sunduk.

Anahtar sözcükler: Conversion disorder, children, sudden visual loss

\section{INTRODUCTION}

Conversion disorder $(\mathrm{CD})$ is classified under the main heading of somatic symptom disorders, and related disorders According to DSM $5{ }^{1}$. It is characterized by impairment in one or more voluntary motor, sensory or neurovegetative functions which can be confused with organic pathologies. There should be an incompatibility between neurological or general medical conditions for explaining these symptoms ${ }^{2}$. In a study conducted in our country, the incidence of 
$\mathrm{CD}$ in the child psychiatric outpatient clinic was reported as $2-3 \%^{3}$.

Retinitis pigmentosa (RP) is an autosomal dominant, autosomal recessive or X-linked hereditary disease of the retina that affects approximately $1 / 3000-4000$ individuals ${ }^{4}$. Typical $\mathrm{RP}$ is characterized by an early loss of bacillus photoreceptors, and signs such as night blindness and narrowing of the visual field occur firstly. Following this, subsequent loss occurs on cone photoreceptors and resulting in it, the visual acuity and macular sensitivity decrease ${ }^{5}$. Visual loss may be a precursor symptom in organic (acute glaucoma, transient ischemic attack, cerebrovascular disease, migraine, etc.) and, rarely, in non-organic diseases ${ }^{6}$. In this case report, the diagnosis of conversion disorder accompanied by a rare sensory symptom (sudden vision loss) after a multisystemic evaluation of a 7-year-old patient was presented.

\section{CASE REPORT}

A 7-year-old girl admitted to the emergency service with the complaint of blurred vision in both eyes, which was first started 4 months ago, then resolved spontaneously and resumed for the last 2 days. The patient has referred to pediatric service and hospitalized for investigating in terms of organic pathologies.

The biochemistry test results of her were found to be normal in the pediatric service. So, she had been consulted with the ophthalmology department because of her blurred vision and rare blackout on the left eye. In ophtalmology examination no urgent pathology was detected. Thereon she referred to the neurology department with the risk of intracranial mass, myasthenia gravis, or related diseases. Brain diffusion MR and sleep EEG of the patient who was consulted with neurology and the results were found to be normal. The diagnosis of myasthenia gravis was excluded due to the absence of fatigue-induced ptosis or gaze restriction in the patient's anamnesis.

She has referred to the ophthalmology department again for analyzing in terms of optic neuritis, the examination results were also found negative. It was determined that there was no refraction defect and her vision was complete, and no pathology was detected in the orbital MR.

Since no organic pathology was found in the examinations performed by the ophthalmology and neurology department and the case was referred to our outpatient clinic with a pre-diagnosis of conversion disorder.
During the evalution in our department, she stated that when she came home from school, she was suddenly unable to see and even walking because she could not see. Also, she indicated that she had a short-term vision loss 4 months ago, but it was not that severe. Questioning the stressor factors, we learned that there were marital problems between the parents, they decided to divorce, and her vision loss started simultaneously after learning about this situation. Moreover, she had witnessed quarrels and physical violence between the parents from time to time. In her family history, her mother had retinitis pigmentosa, her vision loss progressed at an early age, and finally she lost her vision at the age of 20 .

She came to our outpatient clinic in a wheelchair accompanied by a caregiver. She stated that she could not walk because she could not see. The sentence completion test could not be given because of visual loss. Her mood was euthymic and her affect was appropriate. Despite the sudden vision loss, her anxiety was low (la belle indifference). From the onset of her illness, she was happy to see her father more often and to have her parents side by side, and also she was happy to receive her parents attention (secondary gains). During the period of discharge, the parents decided to gave up divorce and afterward her vision loss ameliorated suddenly. Therefore, she was diagnosed with conversion disorder due to the absence of organic pathology, secondary gains, and indifference to the situation and the sudden improvement observed when the stressor factor disappeared. The situation was explained to the family. Suggestions were made on secondary gains and management of the CD process. No medical treatment was initiated. The monthly follow-up of the case is continuing in our outpatient clinic.

\section{DISCUSSION}

Conversion disorder (CD) is a psychiatric disorder that mimics a neurological or other general medical condition, characterized by a stress-induced symptom affecting one or more sensory or voluntary motor functions. Pseudoseizures are the most common form of CD in our country ${ }^{7}$. We examined this case because the complaint of the presentation which was the loss of vision, a rare sensory symptom in CD.

It is known that nonorganic vision loss is most prevalent between the ages of 9-11 in children ${ }^{6}$. In this study, a 7-year-old case was discussed. Head trauma history should be questioned in sudden onset vision loss ${ }^{8}$. There was no head trauma in the anamnesis of our case. Reasons such as cataracts, glaucoma, hereditary diseases, and corneal scarring 
should also be considered when evaluating childhood vision loss ${ }^{9}$. Our patient was also evaluated by an ophthalmologist, and no ophthalmopathology that could cause vision loss was detected.

Retinitis pigmentosa (RP) is an inherited disease that causes an abnormality of photoreceptors (rod and cone) or progressive loss of vision in the retina's pigment epithelium. RP can be inherited in an autosomal dominant, autosomal recessive, or Xlinked fashion ${ }^{10}$. Eventhough the patient's mother had RP, no findings suggestive of retinitis pigmentosa were found in the anamnesis or ophthalmological examination of the patient. Based on these results, the fact that the patient revealed a symptom such as vision loss made us think that she mimicked the symptom of her mother who had a vision loss due to RP.

According to narrative, the child was not seeing her father too much because of her parents' divorcing period. Nevertheless, while she was staying in the hospital, during those ten days, her father came and the symptom did not repeat, and this thought us that it might have a psychogenic origin.

As in our case, the diagnosis of conversion disorder should be considered and psychiatric consultation should be requested in cases where secondary gains are present, symptoms regress when the stress factor disappears, and organic pathology is not found. The most important task of child psychiatrists is to raise awareness and gain insight into the family and the patient about the management of $\mathrm{CD}$ in order to prevent relapse in the future.

\section{REFERENCES}

1. Ndukuba AC, Ibekwe RC, Odinka PC, Muomah $\mathrm{RC}$, Nwoha SO et al. Knowledge of conversion disorder in children by pediatricians in a developing country. Niger J Clin Pract 2015;18:534-7.

2. Baykara S, Atmaca M, Yildirım H. .Comparison of Cerebellum Volumes of the Patients With Healthy Controls' in Conversion Disorder. KSÜ Tip Fak Der 2017;12(3):12-18.

3. Kerimoğlu E, Yalın A. Obsessive-compulsive disorder and hysteria (conversion reaction) in children. Journal of Ankara Medical School 1992; 14:11-18.S

4. Parmeggiani F, Barbaro V, Migliorati A, Raffa $P$, Nespeca $P$ et al. Novel variants of RPGR in $\mathrm{X}$-linked retinitis pigmentosa families and genotype-phenotype correlation. Eur J Ophthalmol 2017 Mar 10;27(2):240-248.

5. Bravo-Gil N, González-del Pozo M, MartínSánchez M, Méndez-Vidal C, Rodríguez-de la Rúa $\mathrm{E}$ et al. Unravelling the genetic basis of simplex Retinitis Pigmentosa cases. Scientific Reports 2017 vol: 7 pp: 41937.

6. Arhan EP, Serdaroğlu A, Sungur G, Aktürk Özçelik AA, Ökten F et al. Non-Organik Görme Kaybi. Turkey Clinical J Pediatr 2009; 18 (2): 143-6.

7. Deveci A, Taskin O, Dinc G, Yilmaz H, Demet $\mathrm{MM}$ et al. Prevalence of pseudoneurologic conversion disorder in an urban community in Manisa, Turkey. Soc Psychiatry Psychiatr Epidemiol 2007;42:857-864.

8. Atkins E, Newman N, Biousse V. PostTraumatic Visual Loss. Rev Neurol Dis 2008;5(2): 73-81.

9. Gilbert CE, Canovas R, Hagan M, Rao S, Foster A. Causes of childhood blindness: results from west Africa, south India and Chile. Eye (Lond) 1993;7 (Pt 1):184-8.

10. Ferrari S, Di Iorio E, Barbaro V, Ponzin D, S. Sorrentino, F et al. Retinitis Pigmentosa: Genes and Disease Mechanisms. Curr Genomics 2011 Jun; 12(4): 238-249. 